level in 19 of 47 heterozygotes, suggesting that the $a_{1}$-AT level may be raised to the normal range under certain physiological or pathological conditions such as infection and pregnancy.

\section{ACKNOWLEDGEMENTS}

The authors express their thanks to Professor S. Imamura and Dr Y. Shinozaki for allowing them to perform the survey, and to Dr E. C. Foulkes for correcting the manuscript.

\section{REFERENCES}

Briscoe, W. A., Kueppers, F., Davis, A. L. \& Bearn, A. G. (1966) Amer. Rev. resp. Dis., 94, 529

Eriksson, S. (1964) Acta med. scand., 175, 197

Eriksson, S. (1965) Acta med. scand., 177, Suppl., p. 432
Ganrot, P. O., Laurell, C.-B. \& Eriksson, S. (1967) Scand. J. clin. Lab. Invest., 19, 205

James, K., Collins, M. L. \& Fudenberg, H. H. (1966) J. Lab. clin. Med., 67, 528

Kueppers, F., Briscoe, W. A. \& Bearn, A. G. (1964) Science, 146, 1678

Kueppers, F., Fallat, R. \& Larson, R. K. (1969) Science, 165,899

Laurell, C.-B. \& Eriksson. S. (1965) Clin. chim. Acta, 11, 395

Lieberman, J. (1969) New Engl. J. Med., 281, 279

Lieberman, J., Mittman, C. \& Schneider, A. S. (1969) J. Amer. med. Ass., 210, 2055

Talamo, R. C., Blennerhassett, J. B. \& Austen, K. F. (1966) New Engl. J. Med., 275, 1301

Talamo, R. C., Allen, J. D., Kahan, M. G. \& Austen, K. F. (1968) New Engl. J. Med., 278, 345

Tarkoff, M. P., Kueppers, F., Miller, W. F. (1968) Amer. J. Med., 45, 220

\title{
Measurements of Concentrations of Human Serum Immunoglobulins *
}

Concentrations of immunoglobulins in human serum are frequently measured for both clinical and research purposes, and the values have been expressed in terms such as $\mathrm{mg} / \mathrm{ml}$. However, there has been little confidence that concentrations, as estimated by different laboratories using different reference materials, are comparable. With the object of improving the uniformity of estimates by different laboratories, a freeze-dried preparation of human serum, coded $67 / 86$, has been assessed for use as a standard for measurements of human serum immunoglobulins IgG, IgA, and IgM by techniques of immunodiffusion (Rowe, Anderson \& Grab, 1970). Part of this batch of material has been established by the World Health Organization ${ }^{1}$ as the International Reference Preparation of Human Immunoglobulins IgG, IgA, and IgM, and international units have been assigned to it such that each ampoule of the International Reference Preparation contains on average $100 \mathrm{IU}$ of IgG, $100 \mathrm{IU}$ of IgA, and $100 \mathrm{IU}$ of IgM. The signatories of this note met recently to consider ways in which the International Reference Preparation might be used to promote uniformity of measurement.

* This Note was drafted in February 1971 by the signatories listed on page 256.

1 WHO Expert Committee on Biological Standardization (1971) Wld Hlth Org. techn. Rep. Ser., No.\$463.

2722C
International collaborative studies have shown that reasonable agreement between estimates can be achieved in the measurement of $\operatorname{IgG}, \operatorname{IgA}$, and $\operatorname{IgM}$ in normal human serum using the International Reference Preparation as a standard. (For example, the ratio of the highest and lowest values obtained by 11 different laboratories on one serum sample was 1.36 for $\operatorname{IgG}, 1.17$ for $\operatorname{IgA}$, and 1.31 for $\operatorname{IgM}$ ). However, estimates in terms of $\mathrm{mg} / \mathrm{ml}$ of the immunoglobulin contents of a solution of the International Reference Preparation, obtained by comparison with purified immunoglobulins using gel-diffusion techniques, showed widely divergent values. The ratio of the highest and lowest values obtained by 9 or 10 different specialized laboratories was 2.2 for IgG, 3.2 for $\operatorname{IgA}$, and 5.0 for IgM (Rowe, Anderson \& Grab, 1971). Such divergence of results is consistent with the present lack of uniformity of the numerous immunoglobulin standards prepared in different laboratories, for which concentrations are usually expressed as $\mathrm{mg} / \mathrm{ml}$. There would be more agreement between laboratories if serum concentrations of IgG, IgA, and IgM were estimated by comparison with the International Reference Preparation, and expressed in terms of International Units per $\mathrm{ml}$.

It is therefore proposed:

(1) That concentrations of $\operatorname{IgG}, \operatorname{IgA}$, and $\operatorname{IgM}$ in working standards, as distributed by manufac- 
turers and others for serum estimation, should be expressed in international units per millilitre, following direct comparison of the working standard with the International Reference Preparation or other suitably calibrated preparation.

(2) That concentrations of IgG, IgA, and IgM in human sera should be expressed in international units per millilitre following comparison with the calibrated working standards. This is of special importance for data that are to be published.

(3) That, to ensure continuity with previous practice, manufacturers and others should continue, for a transitional period, to indicate the estimated immunoglobulin contents of their standards by weight as well as in international units. The relationships between estimated weight and international units for a given immunoglobulin may be expected to differ between different standards; hence the relationship established for any one batch of standards should not be used as a "conversion factor" for any other standard.

(4) That the same principles regarding measurements and expression of serum concentrations of IgG, IgA, and IgM in units should also apply to the measurement of IgD and IgE, for each of which a national research standard is now available (Rowe, Anderson \& Tackett, 1970; Rowe et al., 1970) and national units have been defined. It is hoped that at a later stage international reference preparations of these immunoglobulins will be established and international units defined.

It is recognized that the use of international units to express immunoglobulin content will initially be unfamiliar. International units will come into general use more rapidly if it is realized that they give greater agreement between estimates than is obtainable in other ways at the present time. There is a need to familiarize clinicans, clinical pathologists, and all others involved in measuring immunoglobulin levels with the advantages of these proposals.

It is hoped that the concentrations of $\operatorname{IgG}, \operatorname{IgA}$, and IgM in all standards will be indicated in international units per millilitre by the beginning of 1972. The levels and ranges of serum immunoglobulins in $\mathrm{IU} / \mathrm{ml}$ in populations grouped according to age, race, and locality and in health and disease should be investigated and published as a matter of urgency.

Preparations related to the International Reference Preparation and calibrated in terms of international units are now generally available, free of charge. In the Americas preparation $67 / 95$ is available from the Director, NCI Immunoglobulin Reference Centre, 6715 Electronics Drive, Springfield, Va. 22151, USA. In the United Kingdom, preparation 67/99 is available from the Director, Division of Biological Standards, National Institute for Medical Research, Mill Hill, London, N.W.7., England. Workers elsewhere should request preparation 67/97 from the Director, WHO International Reference Centre for Immunoglobulins, 21 rue du Bugnon, 1011 Lausanne, Switzerland.

The International Reference Preparation of $\mathrm{Hu}$ man Immunoglobulin IgG, IgA, and IgM is available only in limited quantities; in general, it is reserved for the calibration of national standards. For this purpose it may be obtained from the Director, WHO International Laboratory for Biological Standards, Statens Seruminstitut, Amager Boulevard 80, Copenhagen S, Denmark.

The national Research Standards for IgE and IgD are available as follows: the Research Standard for IgE, coded 68/341, and the Research Standard for IgD, coded $67 / 37$, may be obtained from the indicated addresses in London, England, by workers in the United Kingdom, and from the address in Lausanne, Switzerland, by workers elsewhere.

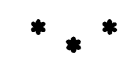

Dr S. G. Anderson, Division of Biological Standards, National Institute for Medical Research, Mill Hill, London, England

Dr D. R. Bangham, Director, Division of Biological Standards, National Institute for Medical Research, Mill Hill, London, England

Dr Irene Batty, Wellcome Research Laboratories, Beckenham, Kent, England

Dr W. Becker, Behringwerke AG, Marburg/Lahn, Federal Republic of Germany

Dr B. Cinader, President, International Union of Immunological Societies, Department of Medical Cell Biology, University of Toronto, Toronto, Canada

Dr M. van der Giessen, Central Laboratory of the Netherlands Red Cross Blood Transfusion Service, Amsterdam, the Netherlands

Dr F. Hymes, Director, Meloy Laboratories, Biological Products Division, Springfield, Va., USA

Dr D. Long, Wellcome Research Laboratories, Beckenham, Kent, England

Dr F. Peetoom, Director of Research, Hyland Laboratories, Costa Mesa, Calif., USA

Dr K. Pondman, Central Laboratory of the Netherlands Red Cross Blood Transfusion Service, Amsterdam, the Netherlands 
Dr M. Raynaud, Chairman, Standardization Committee of the International Union of Immunological Societies, Institut Pasteur, Annexe de Garches, Garches, France Dr C. B. Reimer, Biological Reagents Section, Center for Disease Control, Atlanta, Ga., USA

Dr D. S. Rowe, Director, WHO International Reference Centre for Immunoglobulins, Lausanne, Switzerland

Dr H. G. Schwick, Behringwerke AG, Marburg/Lahn, Federal Republic of Germany

Dr S. Vrancheva, Biological Standardization, World Health Organization, Geneva, Switzerland
REFERENCES

Rowe, D. S., Anderson, S. G. \& Grab, B. (1970) Bull. Wld Hlth Org., 42, 535

Rowe, D. S., Anderson, S. G. \& Grab, B. (1971) Bull. Wld Hlth Org., (In press)

Rowe, D. S., Anderson, S. G. \& Tackett, L. (1970) Bull. Wld Hlth Org., 43, 607

Rowe, D. S., Tackett, L., Bennich, H., Ishizaka, K., Johansson, S. G. O. \& Anderson, S. G. (1970) Bull. Wld Hlth Org., 43, 609

\title{
A Suction Dredge for Collecting Biomphalaria and other Molluscs from Deep Water
}

\author{
by M. A. Prentice ${ }^{1}$ \& G. E. Ealden ${ }^{2}$
}

Snails of the Biomphalaria choanomphala group occur in certain great lakes of Africa both in shallow water and down to depths of at least 40 feet (12 m) (Mandahl-Barth, 1958). Investigation of the significance of these snails as intermediate hosts of Schistosoma mansoni under natural conditions has hitherto been hampered by the difficulty of collecting adequate numbers from deep-water habitats. None of the usual methods of collecting samples of lake-bottom fauna are satisfactory (Webbe, 1965); the Eckman grab will operate only on suitable substrates and samples a very small area during a working day, and although conventional dredges will sample larger areas they cannot be used on rocky or boulder-strewn bottoms.

The suction dredge was constructed in an attempt to overcome these sampling problems. It can be operated continuously over any type of bottom and the collected material is presented as a well-washed, silt-free sample consisting mainly of live molluscs and gravel. The sample from each run may be pooled or, by changing the collecting sieve at intervals, fractionated. Very large areas of bottom can be scanned in a few hours and approximate distribution patterns for various molluscs are quickly visualized.

${ }^{1}$ Senior Entomologist, Vector Control Division, Ministry of Health, Kampala, Uganda.

' Senior Field Officer, Vector Control Division, Ministry of Health, Kampala, Uganda.

\section{Apparatus}

The apparatus consists of a petrol-driven pump mounted on a small boat powered by an outboard motor; material is pumped off the lake bottom through a trailing pipe and discharged into a wiremesh collecting basket (Fig. 1, 2). The pump is of the diaphragm type ${ }^{3}$ and has only one simple flap valve on the intake side. The diaphragm is free at the periphery and acts as its own delivery valve. The generous working clearances of the pump and the flexible diaphragm result in minimal damage to live material (dragonfly nymphs, for example, are delivered unharmed) and small stones up to $3 / 4$ in $(18 \mathrm{~mm})$ diameter pass without damage to the pump. The intermittent suction, characteristic of this type of pump, helps to prevent the inlet being blocked by detritus. Centrifugaltype pumps have been found unsuitable because of their small working clearances.

To preserve the smooth gradient of the intake pipe, and to prevent the outlet becoming blocked by accumulated sand or gravel, the pump is mounted on bearers resting on the gunwales of the boat. The discharge from the pump is directed down a slight gradient into a removable wire sieve (3-5 mm mesh) supported in a frame attached outboard to the side of the boat. For preliminary work over large areas,

Simplite MK III, manufactured by W. B. Selwood, Chandlersford, Hampshire, England. 